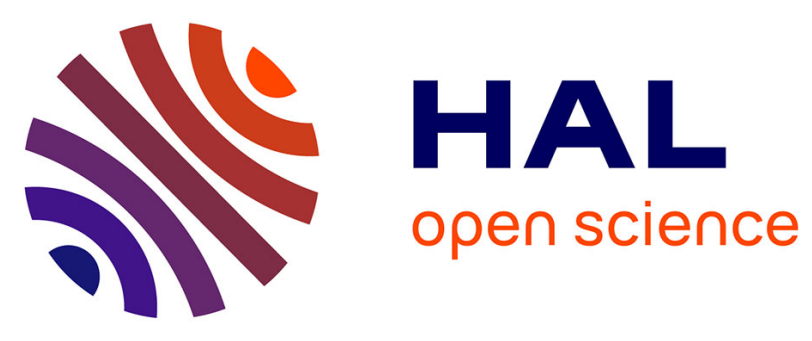

\title{
Amorphous silica nanoparticles do not induce cytotoxicity, cell transformation or genotoxicity in Balb/3T3 mouse fibroblasts.
}

Chiara Uboldi, Guido Giudetti, Francesca Broggi, Douglas Gilliland, Jessica Ponti, François Rossi

\section{To cite this version:}

Chiara Uboldi, Guido Giudetti, Francesca Broggi, Douglas Gilliland, Jessica Ponti, et al.. Amorphous silica nanoparticles do not induce cytotoxicity, cell transformation or genotoxicity in Balb/3T3 mouse fibroblasts.. Mutation Research - Genetic Toxicology and Environmental Mutagenesis, 2012, 745 (1-2), pp.11-20. 10.1016/j.mrgentox.2011.10.010 . hal-02354026

\author{
HAL Id: hal-02354026 \\ https://hal.science/hal-02354026
}

Submitted on 7 Nov 2019

HAL is a multi-disciplinary open access archive for the deposit and dissemination of scientific research documents, whether they are published or not. The documents may come from teaching and research institutions in France or abroad, or from public or private research centers.
L'archive ouverte pluridisciplinaire HAL, est destinée au dépôt et à la diffusion de documents scientifiques de niveau recherche, publiés ou non, émanant des établissements d'enseignement et de recherche français ou étrangers, des laboratoires publics ou privés. 


\title{
Amorphous silica nanoparticles do not induce cytotoxicity, cell transformation or genotoxicity in Balb/3T3 mouse fibroblasts
}

\author{
Chiara Uboldi, Guido Giudetti, Francesca Broggi, Douglas Gilliland, Jessica Ponti*, François Rossi \\ European Commission, Joint Research Centre, Institute for Health and Consumer Protection, Nanobiosciences Unit, TP203, via E. Fermi 2749, 21027, Ispra (VA), Italy
}

\section{A R T I C L E I N F O}

\section{Article history:}

Received 21 October 2011

Accepted 22 October 2011

Available online 7 November 2011

\section{Keywords:}

Amorphous silica nanoparticles

Cytotoxicity

Morphological transformation

Genotoxicity

Uptake

\begin{abstract}
A B S T R A C T
Although amorphous silica nanoparticles $\left(\mathrm{aSiO}_{2} \mathrm{NPs}\right)$ are believed to be non-toxic and are currently used in several industrial and biomedical applications including cosmetics, food additives and drug delivery systems, there is still no conclusive information on their cytotoxic, genotoxic and carcinogenic potential. For this reason, this work has investigated the effects of $\mathrm{aSiO}_{2} \mathrm{NPs}$ on Balb/3T3 mouse fibroblasts, focusing on cytotoxicity, cell transformation and genotoxicity. Results obtained using $\mathrm{aSiO}_{2} \mathrm{NPs}$, with diameters between $15 \mathrm{~nm}$ and $300 \mathrm{~nm}$ and exposure times up to $72 \mathrm{~h}$, have not shown any cytotoxic effect on Balb/3T3 cells as measured by the MTT test and the Colony Forming Efficiency (CFE) assay. Furthermore, $\mathrm{aSiO}_{2} \mathrm{NPs}$ have induced no morphological transformation in Balb/3T3 cells and have not resulted in genotoxicity, as shown by Cell Transformation Assay (CTA) and Micronucleus (MN) assay, respectively. To understand whether the absence of any toxic effect could result from a lack of internalization of the $\mathrm{aSiO}_{2} \mathrm{NPs}$ by Balb/3T3 cells, we have investigated the uptake and the intracellular distribution following exposure to $85 \mathrm{~nm}$ fluorescently-labelled $\mathrm{aSiO}_{2} \mathrm{NPs}$. Using fluorescence microscopy, it was observed that fluorescent $\mathrm{aSiO}_{2} \mathrm{NPs}$ are internalized and located exclusively in the cytoplasmic region. In conclusion, we have demonstrated that although $\mathrm{aSiO}_{2} \mathrm{NPs}$ are internalized in vitro by Balb/3T3 mouse fibroblasts, they do not trigger any cytotoxic or genotoxic effect and do not induce morphological transformation, suggesting that they might be a useful component in industrial applications.
\end{abstract}

\section{Introduction}

During the last 10 years, the use of nanomaterials (at least one dimension $<100 \mathrm{~nm}$ ) in industrial and biomedical applications has increased to the point where important questions on the health effects induced by exposure to nanoparticles (NPs) have arisen. In this context, the Joint Research Centre (JRC) of the European Commission has developed a strategy research plan on nanoparticle toxicology [1] and recently, in cooperation with the Organization of Economical Cooperation and Development (OECD) Working Party on Manufactured Nanomaterials [2], has built up a Reference Nanomaterials program [3].

Silica NPs, which belong to the OECD list of interest and are among the most utilized nanomaterials in industrial nanotechnologies, can occur in a variety of forms: crystalline, simple amorphous or mesoporous. Mesoporous silica particles have a well-defined nanoporous structure and were shown to be good drug carriers [4] and nucleic acid delivery systems [5]. Amorphous silica nanoparticles $\left(\mathrm{aSiO}_{2} \mathrm{NPs}\right)$, on the other hand, are characterized by

\footnotetext{
* Corresponding author Tel.: +39 0332785793; fax: +39 0332785787

E-mail address: jessica.ponti@jrc.ec.europa.eu (J. Ponti).
}

a non-crystalline structure and are currently employed in a wide range of industrial and biomedical applications. The relative ease by which $\mathrm{aSiO}_{2} \mathrm{NPs}$ can be produced in different sizes and with different surface modifications has led to their widespread use in cosmetics (sun creams), dentistry (toothpaste) and paints as well as food and animal-feed additives [6]. In biomedicine, silica nanoparticles are used as drug delivery systems [7,8], in cancer therapy [9] and in cancer diagnostics [10].

Notwithstanding their extensive use, there is evidence of cytotoxicity induced by silica nanoparticles. Many in vitro studies have reported cytotoxic effects following exposure of different cell types to $\mathrm{aSiO}_{2} \mathrm{NPs}$. Amorphous silica has been shown to reduce the viability in several cell types of human origin [11-15] or increase the secretion of reactive oxidative species (ROS) [16-20]. Furthermore, $\mathrm{aSiO}_{2} \mathrm{NPs}$ have also induced cytotoxicity in rodent-derived cells, where NPs have impaired the cell viability and induced the secretion of ROS and pro-inflammatory cytokines such as IL-1 $\beta$ [17,18,21-24].

Currently, few studies have investigated the in vitro cell transformation and the genotoxic potential of silica NPs. Morphological transformation has been reported to take place in Syrian Hamster Embryo (SHE) cells exposed to amorphous silica in the form of diatomaceous earth NPs but not following exposure to pyrogenic 
$\mathrm{aSiO}_{2} \mathrm{NPs}[21,24,25]$. Genotoxic effects, measured as increased micronuclei formation [26] or decreased DNA content [27] or damaged DNA [26], were observed in A549 and HEp-2 [28] cells in the presence of $\mathrm{aSiO}_{2} \mathrm{NPs}$. Nevertheless, single cell gel electrophoresis (SCGE) performed on 3T3-L1 mouse fibroblasts has not shown evidence of genotoxicity following exposure to silica NPs [29].

Due to the great interest in using $\mathrm{aSiO}_{2} \mathrm{NPs}$, uptake and potential toxicity induced by fluorescent particles have also been investigated. Fluorescent $\mathrm{aSiO}_{2} \mathrm{NPs}$ were shown to affect HEp-2 cellular viability [28] and induce genotoxicity in A549 cells [30]. In addition, fluorescent $\mathrm{aSiO}_{2} \mathrm{NPs}$ were observed in the nuclei [28] and in other intracellular compartments such as endosomes and lysosomes [30-32].

In this work, we have investigated the effects induced by $\mathrm{aSiO}_{2} \mathrm{NPs}$ in Balb/3T3 mouse fibroblasts cell line. Our study, in particular, has focused on the cytotoxicity, cell transformation and genotoxicity of $\mathrm{aSiO}_{2} \mathrm{NPs}$, and to this end we have performed the Colony Forming Efficiency (CFE), the Cell Transformation Assay (CTA) and the Micronucleus test (MN), respectively. The goal of this study was to provide additional data on the toxic potential exerted in vitro by $\mathrm{aSiO}_{2} \mathrm{NPs}$ with the same crystalline structure (amorphous) but different sizes. In addition, this work had the aim of increasing knowledge about the ability of $\mathrm{aSiO}_{2} \mathrm{NPs}$ to induce morphological transformation and genotoxicity in vitro.

\section{Materials and methods}

All the in vitro experiments were performed on immortalized Balb/3T3 mouse fibroblasts clone A31-1-1 [33,34]. Cells were distributed, free from bacteria, fungi and mycoplasma, at the passage number 12 by Hatano Research Institute (Japan) in the context of a pre-validation study [35]. Cells were cultivated up to 70-80\% confluence in tissue culture-treated flasks (BD Falcon; Milan, Italy) and passaged weekly. All the assays were performed under normal cell culture conditions $\left(37^{\circ} \mathrm{C}\right.$; $5 \% \mathrm{CO}_{2} ; 95 \%$ humidity).

\subsection{Methods}

\subsubsection{Synthesis and characterization of silica nanoparticles}

Five different types of unlabelled $\mathrm{aSiO}_{2} \mathrm{NPs}$ and one fluorescently-labelled were used in the present study (Table 1). NM-200 and NM-203 belong to the list of nanomaterials of interest to the OECD and they were delivered in powder form, while the synthesis of NRT-808, NRT-817, NRT-820 and NRT-944 has been performed in our laboratory using the following protocol. Briefly, to obtain monodispersed silicon dioxide particles in the range below $80 \mathrm{~nm}$, a strategy based on the recent publication by Hartlen et al. [36] has been adopted. In this method, $\mathrm{aSiO}_{2} \mathrm{NPs}$ were produced in a growth medium of water containing arginine or lysine catalyst. The water/amino acid mixture was placed in a glass vessel and a smaller volume of an immiscible organic liquid (cyclohexane) added and allowed to float above the aqueous phase. If necessary, this bi-phase solution is then heated and allowed to stabilize at the desired reaction temperature with slow stirring of the aqueous layer. Where additional heating was necessary, the reactions were done using CEM Discover S microwave heating system (CEM; Matthews; NC). The choice of microwave heating was found to give improved monodispersivity and better reproducibility when compared to conventional heating methods. At this point tetraethyl orthosilicate (TEOS) was slowly added to the organic phase where it preferentially dissolved. The system was then left under slow stirring for time period of a few hours to several days. During this time, there was a slow diffusion of TEOS from the upper organic layer into the aqueous phase where hydrolysis and condensation occurs with the nucleation and growth of $\mathrm{aSiO}_{2} \mathrm{NPs}$ with narrow size distribution.

\section{Table 1}

Amorphous silica nanoparticles: concentration, origin and declared size.

\begin{tabular}{llll}
\hline Sample name & $\begin{array}{l}\text { Nominal } \\
\text { concentration }\end{array}$ & Origin & $\begin{array}{l}\text { Declared size } \\
(\mathrm{nm})\end{array}$ \\
\hline NM-200 & Powder form & $\begin{array}{l}\text { OECD list of interest; } \\
\text { JRC repository }\end{array}$ & $10-25$ \\
NM-203 & Powder form & $\begin{array}{l}\text { OECD list of interest; } \\
\text { JRC repository }\end{array}$ & $5-30$ \\
NRT-808 & $1.69 \mathrm{mg} / \mathrm{mL}$ & JRC & 35 \\
NRT-817 & $1.53 \mathrm{mg} / \mathrm{mL}$ & JRC & 15 \\
NRT-820 & $1.54 \mathrm{mg} / \mathrm{mL}$ & JRC & 90 \\
NRT-944 & $5 \mathrm{mg} / \mathrm{mL}$ & JRC & 80 \\
\hline
\end{tabular}

The microwave heating system used here permits a maximum batch volume of $100 \mathrm{~mL}$ and this was established as the standard volume for $\mathrm{aSiO}_{2} \mathrm{NPs}$ synthesis by the bi-phase method. An appropriate choice of temperature, catalyst concentration and reaction time was found to allow the production of near monodispersed $\mathrm{aSiO}_{2} \mathrm{NPs}$ with sizes controllable in the range $17-80 \mathrm{~nm}$. Larger particles can be produced by this method but Scanning Electron Microscopy (SEM) analysis has shown that the solutions may be contaminated with a proportion of smaller particles.

For the production of fluorescent silica particles $\left(\mathrm{aSiO}_{2}-\mathrm{Ru} \text { (bipy }\right)_{3}$; NRT-944) the same basic method has been adopted except that a suitable quantity of the $\mathrm{Ru}(\mathrm{bipy})_{3}$ dye (Tris(2,2'-bipyridyl) dichlororuthenium(II) hexahydrate) has been added to the aqueous phase of the reaction mixture. The presence of the dye was found to significantly increase the final size of the particles when compared to those obtained under the equivalent experimental conditions without the dye. Following a detailed study of the effects of experimental conditions, it has been possible to extend the range of particle sizes which may be made by this method so as to be comparable with that previously achieved for pure unlabelled silica NPs. The studies have shown that particle size can again be effectively controlled by varying parameters such as reaction time, temperature $\left(20-60^{\circ} \mathrm{C}\right)$ and the amino acid catalyst concentration (150-3000 mg/L). By careful variation of these three parameters, it has been found to be possible to produce low polydispersivity fluorescent $\mathrm{aSiO}_{2} \mathrm{NPs}$ across the size range from 10 to $120 \mathrm{~nm}$ in a controlled and reproducible way.

Dynamic Light Scattering (DLS) and SEM were used to study the size distribution and morphology of the particles, respectively. Samples were obtained from $100 \mu \mathrm{g} / \mathrm{mL}$ stock solutions. In addition, DLS has been used to determine the polydispersity index (PdI), which is an indicator of the polydispersivity/aggregation of the solution tested. NM-200 and NM-203 powder stocks were dispersed in ultrapure water to a stock concentration of $1 \mathrm{mg} / \mathrm{mL}$ as follows: after weighing $1 \mathrm{mg}$ of NM-200 powder and $1.20 \mathrm{mg}$ of NM-203 powder, the weighed powders were resuspended in ultrapure water to a final concentration of $1 \mathrm{mg} / \mathrm{mL}$ and then bath-sonicated. After $5 \mathrm{~min}$ of sonication, solutions were vortexed for $10 \mathrm{~s}$ and bath-sonicated again for $5 \mathrm{~min}$. For DLS analysis, all stocks were diluted to a final concentration of $100 \mu \mathrm{g} / \mathrm{mL}$ which corresponds to the highest concentration used for the in vitro testing. To check for dispersant-dependent effects on stability/aggregation state, the $\mathrm{aSiO}_{2} \mathrm{NPs}$ were resuspended in ultrapure water and serum-free medium. After dispersion and before analysis, the samples in cell culture medium were incubated for $1 \mathrm{~h}$ at $37^{\circ} \mathrm{C}$ to partially simulate the temperature conditions at which the biological testing was carried out. The DLS measurements were performed on a $1 \mathrm{~mL}$ sample volume on a Zetasizer Nano Zs (Malvern Instruments; Malvern, UK) following the protocols indicated by ISO 13321:1996 and ISO 22412:2008. After 2 min equilibration at $25^{\circ} \mathrm{C}$, each sample underwent 3 measurements. Read number and duration for each measurement were set on 'automatic' on the Zetasizer control software. Only intensity distribution data were considered for the analysis. Averaging the 3 measurements was done using Malvern's proprietary software.

SEM imaging and analysis were performed on samples dispersed in ultrapure water only, after spotting a volume of $5 \mu \mathrm{L}$ of the same samples prepared for DLS on aminated silicon wafers, letting it dry for $10 \mathrm{~min}$ and then eliminating the excess liquid. SEM was performed using a FEI Nova Nanolab 600I (FEI; Eindhoven, The Netherlands). Images were taken at low acceleration voltages of the electrons ( $5 \mathrm{keV})$ in immersion mode. Size distributions for the nanoparticles were then obtained by image analysis of micrographs using the free software Image-J. The images were treated using standard smoothing, background subtraction, binarization and edge detection. The analysis of the particles has been made by measuring each particle area and presenting the results by means of the radius using the spherical particle approximation.

\subsubsection{Basal cytotoxicity: Colony Forming Efficiency (CFE) and MTT assay}

As already published [37], on day zero $200 \mathrm{Balb} / 3 \mathrm{~T} 3$ cells were seeded in $3 \mathrm{~mL}$ of fresh complete medium (Minimum Essential Medium (MEM) $1 \times$; Invitrogen; Carlsbad, CA, USA) supplemented with $10 \%(\mathrm{v} / \mathrm{v})$ fetal bovine serum-Australian origin (Invitrogen; Carlsbad, CA, USA) and $1 \%(\mathrm{v} / \mathrm{v})$ antibiotics $(10,000 \mathrm{U} / \mathrm{mL}$ penicillin and $10,000 \mu \mathrm{g} / \mathrm{mL}$ streptomycin; Invitrogen; Carlsbad, CA, USA) in each 60-mm Petri dish ( 3 replicates per concentration, 3 experiments performed). After $24 \mathrm{~h}$ of incubation under standard cell culture conditions $\left(37^{\circ} \mathrm{C} ; 5 \% \mathrm{CO}_{2} ; 90 \%\right.$ humidity), the treatment suspensions of $\mathrm{aSiO}_{2} \mathrm{NPs}(1 \mu \mathrm{g} / \mathrm{mL}-10 \mu \mathrm{g} / \mathrm{mL}-100 \mu \mathrm{g} / \mathrm{mL})$ were added as aliquots to the cells. Untreated cells and $\mathrm{Na}_{2} \mathrm{CrO}_{4} \cdot 6 \mathrm{H}_{2} \mathrm{O}\left(10^{-3} \mathrm{M}\right)$ were used as negative and positive controls, respectively. Cells were kept in contact with the treatment for $72 \mathrm{~h}$ after which the test compounds were removed and replaced with fresh complete medium. At day 9 after seeding, the colonies were fixed using a solution of $4 \%(\mathrm{v} / \mathrm{v})$ formaldehyde (Sigma-Aldrich; Saint Louis, MO, USA) in Phosphate Buffered Solution (PBS) (Invitrogen; Carlsbad, CA, USA), then stained using $10 \%(v / v)$ of Giemsa (Sigma-Aldrich; Saint Louis, MO, USA) in ultrapure water. After air-drying, colonies (composed of at least 50 cells) were manually scored and counted using a stereomicroscope (Olympus; Milan, Italy). The data obtained were employed in order to define the dose-effect curve at $72 \mathrm{~h}$ and consequently to choose the concentrations to be tested in the cell transformation assay. The results were normalised to the untreated control and expressed as \% CFE ((average of treatment colonies/average of solvent control colonies $) \times 100)$. The corresponding standard error of the mean (sem) has been calculated for 3 independent experiments and at least 3 replicates for each experimental point $(\mathrm{sem}=$ (standard deviation (SD) $/ \sqrt{ }$ number of replicates)). The statistically significant differences for CFE values 
versus controls were calculated by the one-way ANOVA analysis (GraphPadPrism4 statistical software, GraphPad Inc.; La Jolla, CA, USA).

To perform the MTT assay, on day zero 7500 cells/well and 2500 cells/well, in a final volume of $100 \mu \mathrm{L} /$ well of media, were seeded into 96-well plate for $24 \mathrm{~h}$ and $72 \mathrm{~h}$ exposure to $\mathrm{aSiO}_{2} \mathrm{NPs}$, respectively (6 wells per concentration, 3 experiments performed). After $24 \mathrm{~h}$ incubation, Balb/3T3 mouse fibroblasts were exposed to $1 \mu \mathrm{g} / \mathrm{mL}, 10 \mu \mathrm{g} / \mathrm{mL}$ and $100 \mu \mathrm{g} / \mathrm{mL}$ of $\mathrm{aSiO}_{2} \mathrm{NPs}$ for $72 \mathrm{~h}$. At the end of the incubation, cells were washed twice with fresh complete cell culture medium to remove unbound and non-internalized $\mathrm{aSiO}_{2} \mathrm{NPs}$, and then cells were incubated with MTT (1:10 in complete cell culture medium; $100 \mu \mathrm{L} /$ well; MTT stock solution: $5 \mathrm{mg}$ MTT/1 mL PBS; 3-(4,5-dimethylthiazol-2-yl)-2,5-diphenyltetrazolium bromide; Sigma-Aldrich; Saint Louis, MO, USA). After a 2 h incubation $\left(37^{\circ} \mathrm{C} ; 5 \%\right.$ $\mathrm{CO}_{2} ; 90 \%$ humidity) $100 \mu \mathrm{L} /$ well of lysis solution, composed of $20 \mathrm{~g}$ sodium dodecyl

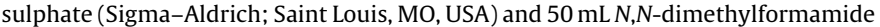
(Sigma-Aldrich; Saint Louis, MO, USA) in ultrapure water, was pipetted and cells were incubated overnight. Absorbance was acquired the next day at $540 \mathrm{~nm}$ using the plate reader FLUOstar Omega (BMG Labtech $\mathrm{GmbH}$; Offenburg, Germany). The results were normalized to the untreated control and expressed as \% viability. The mean value was calculated for 3 independent experiments and at least 3 replicates for each experimental point (sem $=(\mathrm{SD} / \sqrt{ }$ number of replicates). Statistical analysis was performed applying unpaired $t$-test (GraphPadPrism4 statistical software, GraphPad Inc.; La Jolla, CA, USA).

\subsubsection{Cell transformation studies by Cell Transformation Assay (CTA)}

On day zero, $2 \times 10^{4}$ Balb/3T3 cells were seeded in $6 \mathrm{~mL}$ of complete fresh medium Minimum Essential Medium (MEM) 1× supplemented with 10\% (v/v) fetal bovine serum-Australian origin and antibiotics $(10,000 \mathrm{U} / \mathrm{mL}$ penicillin and $10,000 \mu \mathrm{g} / \mathrm{mL}$ streptomycin) in $100 \mathrm{~mm}$-Petri dish (5 replicates per concentration). After $24 \mathrm{~h}$, the treatment suspensions were administered in the desired concentrations by adding aliquots of NP preparations. Non-treated Balb/3T3 cells and cells exposed to $4 \mu \mathrm{g} / \mathrm{mL}$ methylcholanthrene (Sigma-Aldrich; Saint Louis, MO, USA), which is a well-known carcinogenic compound, were used as negative and positive controls, respectively. At the end of exposure $(72 \mathrm{~h})$, medium containing $\mathrm{aSiO}_{2} \mathrm{NPs}$ was removed and replaced with Dulbecco's modified Eagle's medium/F12 (DMEM/F12) with high glucose, L-glutamine $(365 \mathrm{mg} / \mathrm{L})$ and sodium bicarbonate (1200 mg/L) (Invitrogen; Carlsbad, CA, USA) supplemented with $2 \%(\mathrm{v} / \mathrm{v})$ fetal bovine serum-Australian origin, $2 \mu \mathrm{g} / \mathrm{mL}$ insulin (Sigma-Aldrich; Saint Louis, MO, USA) and $1 \%$ antibiotics (Invitrogen; Carlsbad, CA, USA). The culture medium was changed twice a week, and on days 31-35 cells were fixed with $4 \%(v / v)$ of formaldehyde in PBS. Subsequently, cells were stained with a $10 \%(\mathrm{v} / \mathrm{v})$ Giemsa solution in ultrapure water. The dishes were air-dried and observed using a stereomicroscope (Olympus; Milan, Italy) in order to detect and count only morphologically transformed colonies (type-III foci), as described from the International Agency for Cancer Research (IARC) Working-Group [38]. Transformation results were expressed as transformation frequency $\left(T_{\mathrm{f}}\right)$ (5 replicates per concentration, 3 experiments performed) using the following formula: $T_{\mathrm{f}}=[A /(B \times C \times D)]$, where $A=$ total number of type-III foci per treatment; $B=$ CFE (\%)/100; $C=$ plating efficiency (\%)/100; $D=$ number of cells seeded $\times$ number of plates; plating efficiency $(\%)=$ number of colonies formed in the control $\times 100 / 200$, and 200 is the total number of cells seeded in one CFE dish.

The probability of a neoplastic event occurring per surviving cell was determined by using the F-Fisher exact test and was considered statistically significant versus untreated control only when $p<0.05$ [39].

\subsubsection{Genotoxicity studies by Micronucleus (MN) test}

On day zero, $3 \times 10^{5} \mathrm{Balb} / 3 \mathrm{~T} 3$ mouse fibroblasts were seeded in $4 \mathrm{~mL}$ of complete medium Minimum Essential Medium (MEM) $1 \times$ supplemented with $10 \%(\mathrm{v} / \mathrm{v})$ fetal bovine serum-Australian origin and antibiotics $(10,000 \mathrm{U} / \mathrm{mL}$ penicillin and $10,000 \mu \mathrm{g} / \mathrm{mL}$ streptomycin) in each well (1 replicate per concentration) of a 6 wells per plate. $24 \mathrm{~h}$ after seeding, the Balb/3T3 cells were treated with NP suspensions and incubated for $24 \mathrm{~h}$. Non-treated cells and Balb/3T3 mouse fibroblasts exposed to $0.5 \mu \mathrm{M}$ mitomycin C (Kyowa Italiana Farmaceutici; Milano, Italy) were used as negative and positive control, respectively. At the end of the exposure period, the treatment was removed and each well washed twice with PBS. To block cell division, $4.5 \mu \mathrm{g} / \mathrm{mL}$ cytochalasin B (Sigma-Aldrich; Saint Louis, MO, USA) was added to $4 \mathrm{~mL}$ of fresh complete culture medium per well. After a $24 \mathrm{~h}$ incubation (day 3 ), the cells were trypsinized and harvested in PBS. The cell suspensions were centrifuged $(250 \times g)$ and the pellets treated first with a prefixing (methanol:acetic acid, 3:5) and then with a fixing solution (methanol:acetic acid, 6:1). Fixed cells were dropped on glass slides and air-dried overnight. The slides ( 2 replicates for each sample) were stained with a $2 \%(\mathrm{v} / \mathrm{v})$ Giemsa solution in ultrapure water and air-dried. The results ( 2 replicates per concentration, 3 experiments performed) were analyzed by calculating the frequency of binucleated micronucleated (BNMN) cells as the number of binucleated cells containing one or more micronuclei per 1000 binucleated cells. Statistical analysis was performed by F-Fisher exact test and differences versus solvent control were considered statistically significant at $p<0.05$.

\subsubsection{Uptake of fluorescent amorphous silica nanoparticles using microscopy} studies

For microscopy studies, on day zero $1.5 \times 10^{5}$ Balb/3T3 cells were plated onto 4-chamber polystyrene vessel tissue culture-treated glass slides (BD Falcon; Milan,
Table 2

DLS analysis of $\mathrm{aSiO}_{2} \mathrm{NPs}(100 \mu \mathrm{g} / \mathrm{mL})$ in ultrapure water and serum-free cell culture medium.

\begin{tabular}{lcl}
\hline & $\begin{array}{l}\text { Polydispersity } \\
\text { index } \pm \text { SD }\end{array}$ & $\begin{array}{l}\text { Mean particle } \\
\text { diameter }(\mathrm{nm}) \pm \text { SD }\end{array}$ \\
\hline \multicolumn{2}{l}{ Sample analysis in ultrapure water } & \\
NM-200 & $0.506 \pm 0.058$ & $\begin{array}{l}\text { Data quality too poor } \\
\text { NM-203 }\end{array}$ \\
NRT-808 & $0.123 \pm 0.021$ & $37.91 \pm 7.51$ \\
NRT-817 & $0.016 \pm 0.011$ & $17.42 \pm 0.16$ \\
NRT-820 & $0.054 \pm 0.011$ & $89.99 \pm 0.87$ \\
NRT-944 & $0.043 \pm 0.017$ & $81.63 \pm 0.42$ \\
Sample analysis in serum-free cell culture medium & \\
NM-200 & $0.623 \pm 0.096$ & $332.6 \pm 11.42$ \\
NM-203 & $0.125 \pm 0.046$ & $187.3 \pm 7.76$ \\
NRT-808 & $0.079 \pm 0.008$ & $39.39 \pm 0.13$ \\
NRT-817 & $0.526 \pm 0.126$ & $16.08 \pm 0.81$ \\
NRT-820 & $0.073 \pm 0.008$ & $99.69 \pm 0.88$ \\
NRT-944 & $0.052 \pm 0.003$ & $89.98 \pm 0.89$ \\
\hline
\end{tabular}

Table 3

SEM image analysis results of $\mathrm{aSiO}_{2} \mathrm{NPs}(100 \mu \mathrm{g} / \mathrm{mL})$ in ultrapure water.

\begin{tabular}{lclr}
\hline Particle & \multicolumn{1}{c}{$\begin{array}{l}\text { Mean particle } \\
\text { diameter }(\mathrm{nm}) \pm \mathrm{SD}\end{array}$} & $\begin{array}{l}\text { Mean particle diameter } \\
(\mathrm{nm}) \pm \mathrm{SD}(2)\end{array}$ & Particle number \\
\hline NRT-808 & $25 \pm 7.3$ & & 1495 \\
NRT-817 & $16.4 \pm 2.9$ & & 868 \\
NRT-820 & $38 \pm 24$ & $91 \pm 25$ & 2419 \\
NRT-944 & $70 \pm 14$ & & 216 \\
\hline
\end{tabular}

Italy) in $3 \mathrm{~mL}$ of complete Minimum Essential Medium (MEM) $1 \times$ and cultivated under standard culture conditions. After 1 day of cultivation, the cells were exposed for $6 \mathrm{~h}, 24 \mathrm{~h}$ and $72 \mathrm{~h}$ to $200 \mu \mathrm{g} / \mathrm{mL} \mathrm{aSiO}_{2} \mathrm{NPs}$ labelled with the fluorescent dye $\mathrm{Ru}$ (bipy) $)_{3}$. At the end of the exposure Balb/3T3 cells were fixed with $4 \%(\mathrm{v} / \mathrm{v})$ of formaldehyde in PBS and nuclei stained using Hoechst-33342 (Invitrogen; Carlsbad, CA, USA) diluted 1:1200 in PBS. After staining, cells were washed in PBS/Tween-20 solution and mounted for microscopy using GelMount (DAKO; Glostrup, Denmark). Images were acquired with an Axiovert 200M inverted microscope (Carl Zeiss; Jena, Germany) equipped with ApoTome slide module and AxioVision 4.8 software (Carl Zeiss; Jena, Germany), using $40 \times / 1.0$ objective lens. Images were acquired using a black\&white AxioCam MRm (Carl Zeiss; Jena, Germany) and pseudocolors were applied after image acquisition.

\section{Results}

\subsection{Synthesis and characterization of silica nanoparticles}

DLS analysis of the solutions was first performed in ultrapure water at the final concentration of $100 \mu \mathrm{g} / \mathrm{mL}$. The DLS analysis of the dispersions in ultrapure water (Table 2 ) resulted in PdI numbers in agreement with a good monodispersity of the samples while the measured sizes were consistent with the values obtained from measurements of the stock suspensions. SEM imaging and subsequent statistical analysis performed on the samples have confirmed the DLS sizing for the NRT-817 sample (Fig. 1b), while the NRT-808 (Fig. 1a) and NRT-944 (Fig. 1f) samples have shown a difference in size in the range of $10 \mathrm{~nm}$, but also a higher SD (Table 3). The NM-200 and NM-203 dispersions were exceptions to these considerations. The NM-200 dispersion has shown high PdI and an overall data quality too poor to allow for data fitting, which deemed the sample to be not suitable for DLS analysis. The high PdI value and the noisy baseline of the relative correlogram (Fig. 2) have indicated the presence of aggregates and/or agglomerates precipitating in the sample. This has also been confirmed by SEM images, clearly showing clumps of aggregated and/or agglomerated silica nanoparticles in the sample (Fig. 1d). Furthermore, the NM-203 dispersion has shown a PdI (Table 2) that is in agreement with a fairly monodispersed state of the NPs, but the calculated size does not correspond to the declared one (see Table 1), suggesting that the preparation 

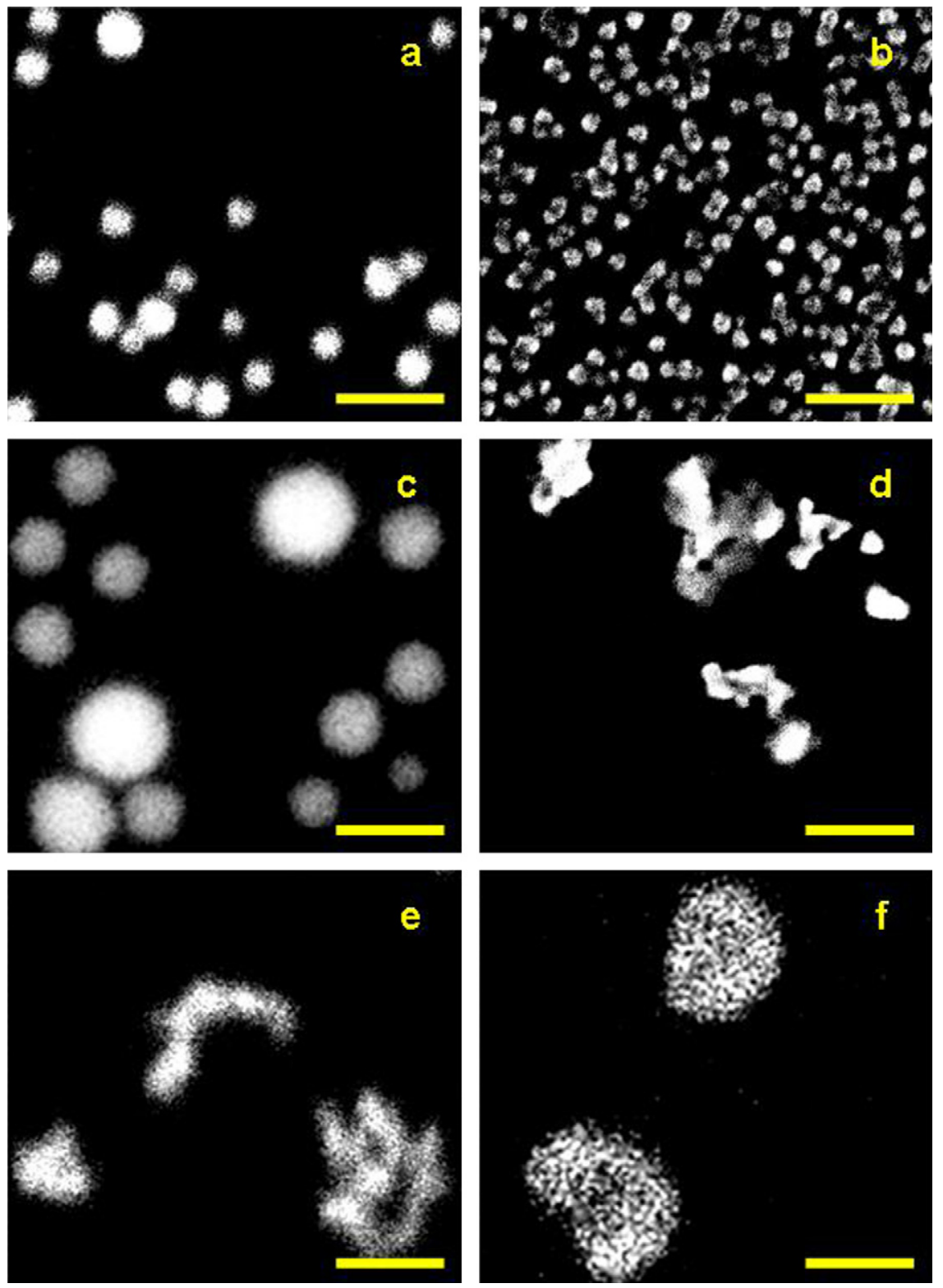

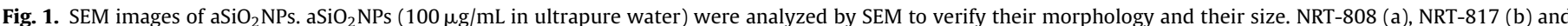

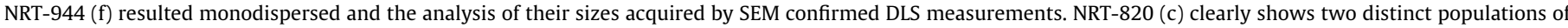
different size ( $40 \mathrm{~nm}$ and $80 \mathrm{~nm}$ ), while NM-200 (d) and NM-203 (e) formed aggregates/agglomerates and the image analysis could not be performed. Size bar: 100 nm.

procedure has generated a monodispersed sample but not to the original NPs size. In fact, SEM imaging has revealed the presence of clumps of nanoparticles also in this case (Fig. 1e).

DLS analysis of NRT-820 has revealed a very low PdI classifying it as monodispersed. In contrast to this, SEM imaging and statistical analysis (Table 3 and Fig. 1c) have shown clearly that NRT-820 is actually constituted of two distinct size populations of around $40 \mathrm{~nm}$ and $80 \mathrm{~nm}$. This result in particular underlines the necessity of integrating DLS data with different characterization techniques, to comprehensively estimate the size of nanoparticles to be used in toxicological in vitro testing and then correctly correlating it with the eventually observed biological effects.

When the DLS analysis of the $\mathrm{aSiO}_{2} \mathrm{NPs}$ was performed in serumfree cell culture medium (Table 2 ), we have observed that particles maintained the same dispersity status as their counterparts dispersed in ultrapure water. The mean particle size of the samples was found to be only slightly increased, showing that they maintain reasonable stability even in a saline solution. Only the NRT-817 sample has shown a substantial change in dispersity, given by the appearance of a secondary population of differently sized NPs aggregates and/or agglomerates in the range of $200 \mathrm{~nm}$. Size distribution analysis by volume has indicated that this population represents only $0.2 \%$ of the sample (data not shown).

An overall review of the characterization data has shown that there is little effect on stability of nanoparticles when dispersed in serum-free cell culture medium, and that the $\mathrm{aSiO}_{2} \mathrm{NPs}$ suspensions derived from dry powders (NM-200 and NM-203) were difficult to disperse back into a monodispersed form. Suspensions have maintained an aggregated/agglomerated state, thus greatly increasing the characteristic size at which they are biologically tested. In addition, an important issue arises when examining data from the NRT-820 sample, in which the DLS has been unable to 


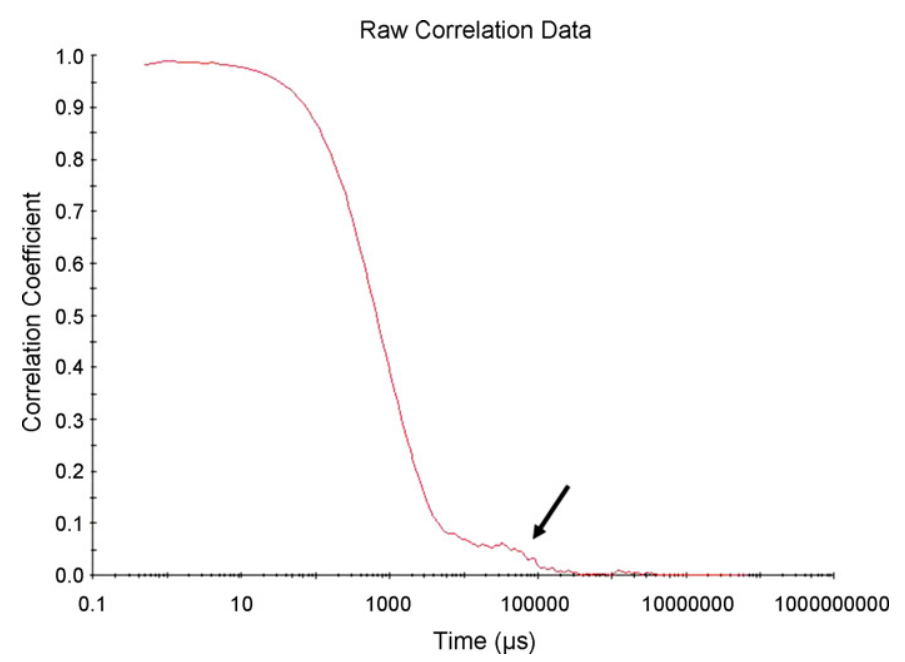

Fig. 2. Agglomeration and/or aggregation of NM-200. The noisy baseline of the correlogram (indicated by the arrow) indicates the presence of agglomerate and aggregates of particles precipitating in the sample.

separate the two size populations that are clearly visible in SEM imaging and the relative statistical analysis. This is due to a technical limitation of DLS, which is not well adapted to analysis of this type of multi-dispersed sample [40]. The inability of the technique to detect the $40 \mathrm{~nm}$ particles in the presence of the $80 \mathrm{~nm}$ particles is primarily the result of the non-linear variation of light scattering as a function of size, which increases with the sixth power of their radius [41,42] effectively masking the presence of the smaller particles. The implication of this consideration is that when using the DLS technique for nanoparticle size characterization, coupling it with one or more different characterization techniques, such as SEM, is a must.

\subsection{Basal cytotoxicity studies by Colony Forming Efficiency (CFE) assay}

The cytotoxic potential of water dispersed $\mathrm{aSiO}_{2} \mathrm{NPs}$ NRT-808, NRT-817 and NRT-820, and NM-200 and NM-203, which were delivered in powder form from OECD, has been investigated by CFE assay in Balb/3T3 mouse fibroblasts. $1 \mu \mathrm{g} / \mathrm{mL}, 10 \mu \mathrm{g} / \mathrm{mL}$ and $100 \mu \mathrm{g} / \mathrm{mL}$ were selected as test concentrations and the exposure has been of $72 \mathrm{~h}$.

As shown in Fig. 3, aSiO ${ }_{2}$ NPs have not induced any significant impairment of CFE in Balb/3T3 cells in vitro, suggesting that neither the synthesis procedure nor particle size and particle agglomeration/aggregation has been responsible for cytotoxicity. Compared to the untreated control $(100 \% \mathrm{CFE} \pm 1.3) 1 \mu \mathrm{g} / \mathrm{mL}$ NM200 resulted slightly toxic but the reduction in colony formation $(92.99 \% \mathrm{CFE} \pm 4.86)$ has not been significant. Similarly, $100 \mu \mathrm{g} / \mathrm{mL}$ NM-203 have induced a non-significant $(93.5 \% \mathrm{CFE} \pm 6.61)$ cytotoxic effect in Balb/3T3 cells after $72 \mathrm{~h}$ exposure. The exposure of Balb/3T3 cells to the other $\mathrm{aSiO}_{2} \mathrm{NPs}$ investigated and at different concentrations has not induced any effect on CFE, with all the values obtained being in the range between $97.24 \% \mathrm{CFE} \pm 3.15$ $(10 \mu \mathrm{g} / \mathrm{mL}$ NRT-808) and $106.28 \% \mathrm{CFE} \pm 5.18(100 \mu \mathrm{g} / \mathrm{mL}$ NRT-820), values which are not statistically significant compared to the negative control (untreated cells).

MTT assay (Fig. 4) has, in contrast, shown a slight but significant reduction of the viability of Balb/3T3 cells after $72 \mathrm{~h}$ in vitro exposure to NRT-820 ( $80 \mathrm{~nm}$ nominal size diameter). In fact, a concentration-dependent impairment of the viability of Balb/3T3 mouse fibroblast has been measured. Measurements of Balb/3T3 cells exposed to $1 \mu \mathrm{g} / \mathrm{mL}, 10 \mu \mathrm{g} / \mathrm{mL}$ and

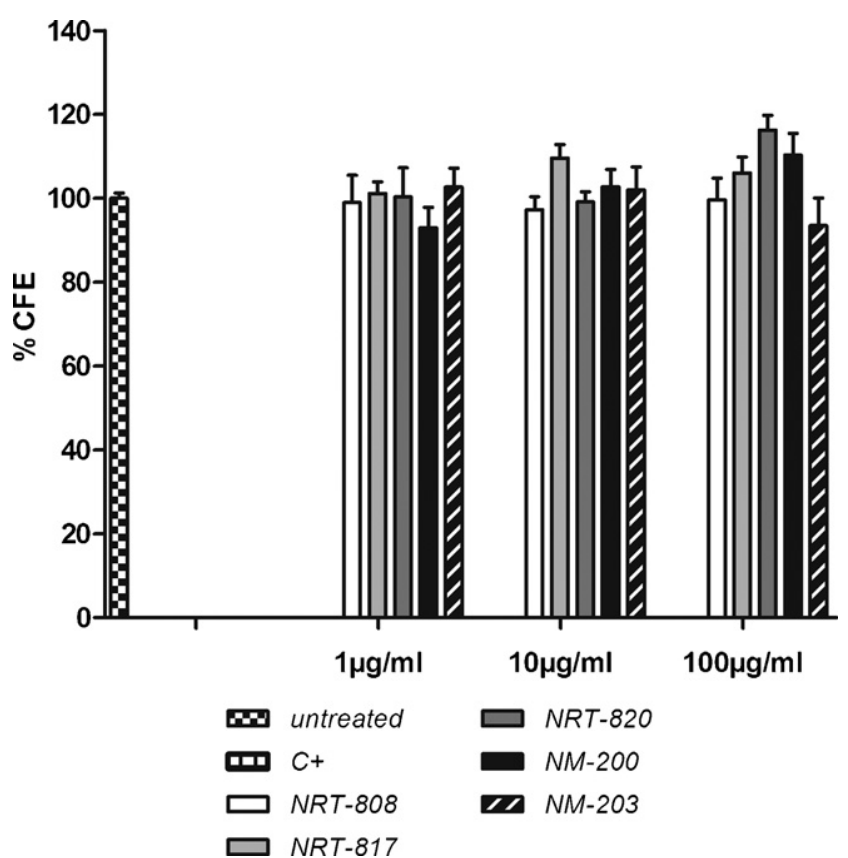

Fig. 3. Colony forming efficiency of Balb/3T3 cells exposed for $72 \mathrm{~h}$ to $\mathrm{aSiO}_{2} \mathrm{NPs}$. Cells were exposed for $72 \mathrm{~h}$ to increasing concentrations of $\mathrm{aSiO}_{2} \mathrm{NPs}$ $(1 \mu \mathrm{g} / \mathrm{mL}-10 \mu \mathrm{g} / \mathrm{mL}-100 \mu \mathrm{g} / \mathrm{mL})$. After fixation and counterstaining, colonies were manually counted. Data were analyzed in comparison to the untreated control and evaluated by one-way ANOVA. $\mathrm{aSiO}_{2} \mathrm{NPs}$ did not induce any cytotoxic effect in Balb/3T3 cells, suggesting that not size not their synthesis method are responsible for cytotoxicity. Mean of 3 independent experiments \pm standard error of the mean (sem).

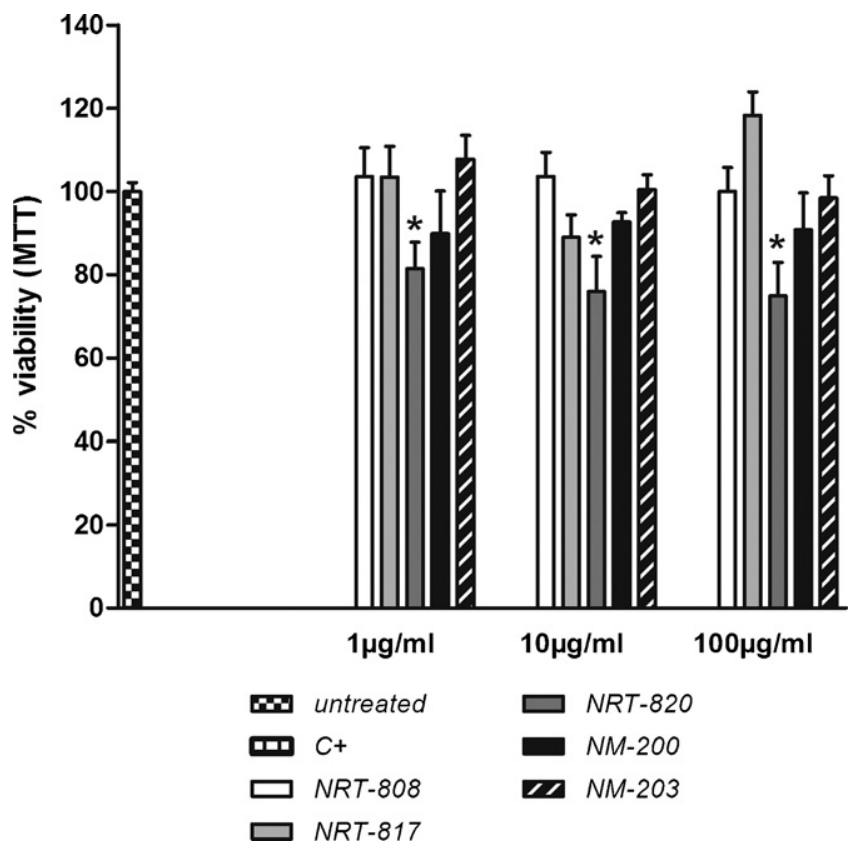

Fig. 4. MTT assay on Balb/3T3 cells exposed for $72 \mathrm{~h}$ to $\mathrm{aSiO}_{2} \mathrm{NPs}$. Cells were exposed for $72 \mathrm{~h}$ to increasing concentrations of $\mathrm{aSiO}_{2} \mathrm{NPs}(1 \mu \mathrm{g} / \mathrm{mL}-10 \mu \mathrm{g} / \mathrm{mL}-100 \mu \mathrm{g} / \mathrm{mL})$. At the end of the incubation period, cells were washed and then incubated with MTT solution (1:10 in complete cell culture medium). After $2 \mathrm{~h}$ incubation, lysis buffer was pipetted in each well and the next day absorbance was acquired at $540 \mathrm{~nm}$ with a plate reader. Data were analyzed in comparison to the untreated contro and evaluated by unpaired $t$-test. Exposure to $\mathrm{aSiO}_{2} \mathrm{NPs}$ NRT-820 ( $80 \mathrm{~nm}$ declared size diameter) induced a slightly significant cytotoxic effect in Balb/3T3 cells. Mean of 3 independent experiments \pm standard error of the mean (sem). ${ }^{*} p<0.05$. The positive control $\left(\mathrm{Na}_{2} \mathrm{CrO}_{4} 1000 \mu \mathrm{M}\right)$ induced complete cell death as expected and the histogram value is equal to 0 . 


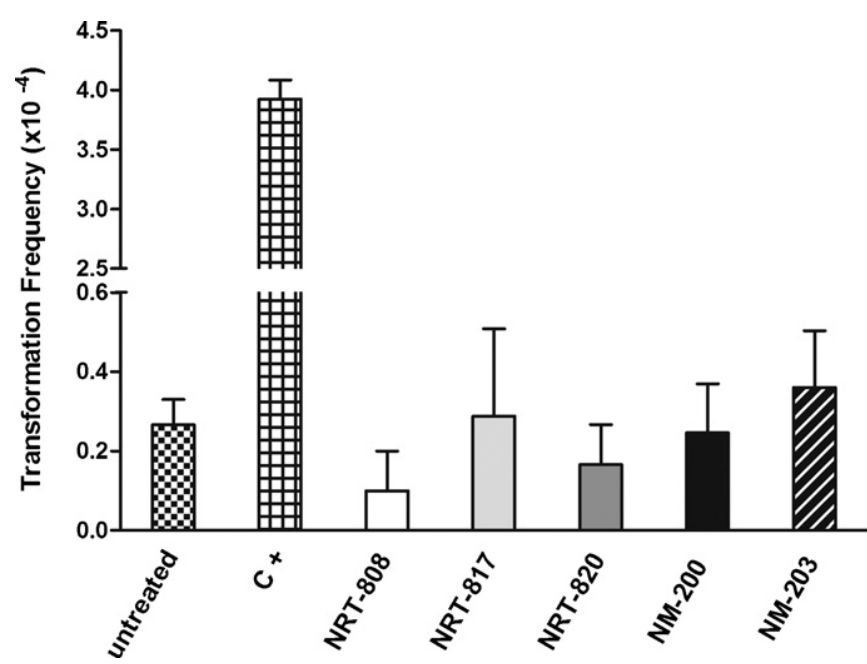

Fig. 5. Cell transformation assay on Balb/3T3 cells exposed to $\mathrm{aSiO}_{2} \mathrm{NPs}$ for $72 \mathrm{~h}$. $\mathrm{aSiO}_{2} \mathrm{NPs}$ were tested at the fixed concentration of $100 \mu \mathrm{g} / \mathrm{mL}$. After exposure $(72 \mathrm{~h}$ ), cells were cultured up to day 35 , then fixed and stained, and type-III foci were counted. Exposure to $\mathrm{aSiO}_{2} \mathrm{NPs}$ did not exert any morphological transformation in Balb/3T3 mouse fibroblasts. The statistical significance was evaluated by F-Fisher exact test $\left({ }^{* * *} p<0.001\right)$ in respect to untreated control. Mean of 3 independent experiments \pm standard error of the mean (sem). Methylcholanthrene, a well-known carcinogenic compound, was used as positive control $(\mathrm{C}+)$. The positive control $\left(\mathrm{Na}_{2} \mathrm{CrO}_{4} 1000 \mu \mathrm{M}\right)$ induced complete cell death as expected and the histogram value is equal to 0 .

$100 \mu \mathrm{g} / \mathrm{mL}$ NRT-820 showed viability of $81.44 \pm 6.36,75.96 \pm 8.44$ and $74.86 \pm 8.10$ respectively, when expressed as percentage of the untreated control $(100 \%$ viability \pm 2.13$)$. In the presence of the other silica particles investigated in this work no reduced Balb/3T3 cells viability has been shown by MTT assay.

\subsection{Cell transformation studies by Cell Transformation Assay (CTA)}

Amorphous $\mathrm{SiO}_{2} \mathrm{NPs}$ were tested for their carcinogenic potential by CTA. $\mathrm{aSiO}_{2} \mathrm{NPs}$, those selected from OECD list (NM-200 and NM-203) and those synthesized in water solution (NRT808, NRT-817 and NRT-820) have not exerted any morphological transformation in Balb/3T3 cells after $72 \mathrm{~h}$ exposure (Fig. 5). When test samples were compared with untreated controls, FFisher exact test did not reveal any significant difference in the transformation frequency $\left(T_{\mathrm{f}}\right)$, which is an indicator of the carcinogenic potential exerted by NPs. Compared to the untreated cells $\left(T_{\mathrm{f}}=0.266 \times 10^{-4} \pm 0.10\right) \mathrm{aSiO}_{2} \mathrm{NPs}$ in water solution have not induced the formation of type-III foci in Balb/3T3 cells in vitro. In fact, the transformation frequency obtained for NRT-808, NRT-817 and NRT-820 corresponded to $0.1 \times 10^{-4} \pm 0.1,0.288 \times 10^{-4} \pm 0.22$ and $0.166 \times 10^{-4} \pm 0.10$, respectively. Similarly, compared to the negative control, NM-200 $\left(T_{\mathrm{f}}=0.246 \times 10^{-4} \pm 0.12\right)$ and NM$203\left(T_{\mathrm{f}}=0.360 \times 10^{-4} \pm 0.14\right)$ did not induce any significant morphological transformation in Balb/3T3 cells. In contrast, methylcholanthrene, which is a well-known carcinogenic compound, induced extremely significant formation of type-III foci $\left(T_{\mathrm{f}}=3.924 \times 10^{-4} \pm 0.16\right)$.

These results indicate that, as already shown by CFE, size and synthesis method does not play any role in the carcinogenic potential of the $\mathrm{aSiO}_{2} \mathrm{NPs}$ we have selected for our study.

\subsection{Genotoxicity studies by Micronucleus (MN) test}

The genotoxic potential of $\mathrm{aSiO}_{2} \mathrm{NPs}$ has been investigated by the micronucleus assay. At the concentration of $100 \mu \mathrm{g} / \mathrm{mL}$,

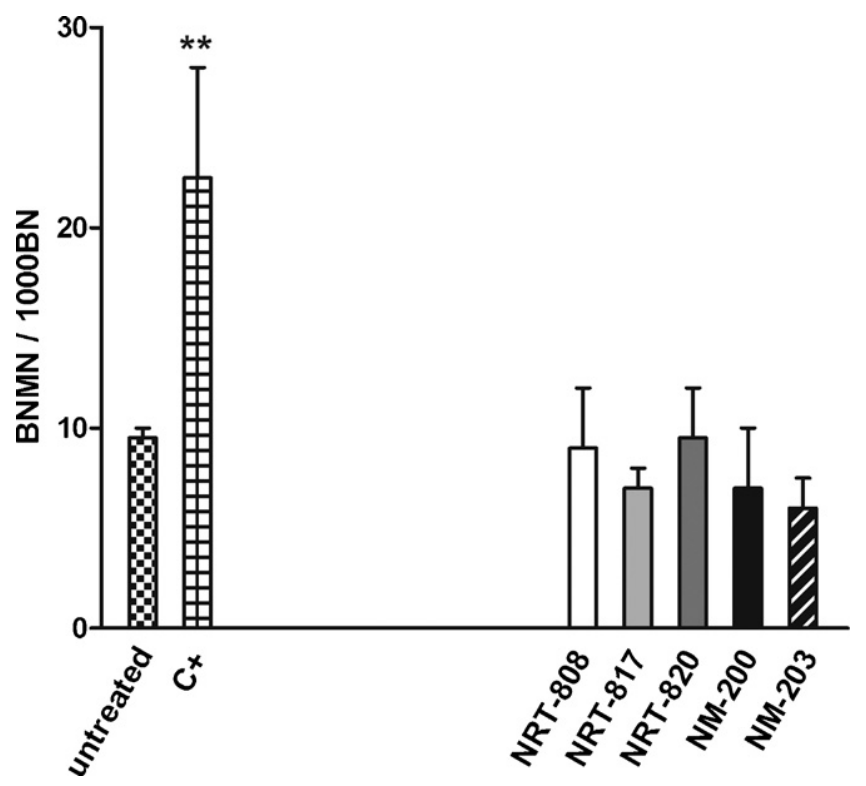

Fig. 6. Micronucleus assay on Balb/3T3 cells exposed to $\mathrm{aSiO}_{2} \mathrm{NPs}$ for $24 \mathrm{~h}$. $\mathrm{aSiO}_{2} \mathrm{NPs}$ were tested at the fixed concentration of $100 \mu \mathrm{g} / \mathrm{mL}$. Compared to untreated control cells, $\mathrm{aSiO}_{2} \mathrm{NPs}$ did not induce genotoxicity in Balb/3T3 mouse fibroblasts. The statistical significance was evaluated by Fisher exact test $\left({ }^{* *} 0.001>p>0.05\right)$ in respect to untreated control. Mean of 2 independent experiments \pm standard error of the mean (sem). Cytochalasin B $(4.5 \mu \mathrm{g} / \mathrm{mL})$ was used as positive control ( + ). $\mathrm{BNMN}=$ binucleated micronucleated cells; $\mathrm{BN}$ = binucleated cells.

$\mathrm{aSiO}_{2} \mathrm{NPs}$ did not induce any significant formation of micronuclei in Balb/3T3 cells in vitro (Fig. 6). In fact, the frequency of binucleated micronucleated (BNMN) Balb/3T3 mouse fibroblasts per 1000 binucleated (BN) cells corresponded to $9 \mathrm{BNMN} \pm 3,7 \mathrm{BNMN} \pm 1$ and 9.5 BNMN \pm 2.5 after 24 h exposure to NRT-808, NRT-817 and NRT820 , respectively. Therefore, compared to the untreated control ( 9.5 $\mathrm{BNMN} \pm 0.5) \mathrm{aSiO}_{2} \mathrm{NPs}$ did not trigger the formation of micronuclei, suggesting that neither the size diameter nor the particles' synthesis procedure induces genotoxicity.

Our results indicate that for $\mathrm{aSiO}_{2} \mathrm{NPs}$, particle size does not play a role in genotoxicity as no significant differences were observed in Balb/3T3 cells exposed to $\mathrm{aSiO}_{2} \mathrm{NPs}$ of different sizes.

\subsection{Internalization of fluorescent amorphous silica nanoparticles}

To verify if the absence of any cytotoxic, cell transformation or genotoxic effect on Balb/3T3 cells by $\mathrm{aSiO}_{2} \mathrm{NPs}$ was simply because NPs were not internalized, the uptake and the in vitro internalization of $85 \mathrm{~nm}$-sized $\mathrm{aSiO}_{2}-\mathrm{Ru}$ (bipy) $)_{3}$ in $\mathrm{Balb} / 3 \mathrm{~T} 3$ cells has been investigated by fluorescent microscopy. We have chosen $85 \mathrm{~nm}$-sized particles (NRT-944) because, as previously shown, for CFE, CTA and MN assays were performed using $\mathrm{aSiO}_{2} \mathrm{NPs}$ with equivalent diameter and surface charge (NRT820).

Using optical microscopy we observed that after $6 \mathrm{~h}$ exposure (Fig. 7a-c) $\mathrm{aSiO}_{2}-\mathrm{Ru}$ (bipy) $)_{3}$ particles accumulated in the cytoplasmic region, and the internalization of particles was confirmed by performing Z-stack series of the samples followed by a 3D reconstruction of the images.

Compared to $6 \mathrm{~h}$ exposure, after $24 \mathrm{~h}$ (Fig. $7 \mathrm{~d}-\mathrm{f}$ ) a higher number of cells were observed under the microscope and after $72 \mathrm{~h}$ (Fig. $7 \mathrm{~g}-\mathrm{i}$ ) cells were confluent. In addition, particles were taken up by Balb/3T3 cells and they were stored in the cytoplasm (Fig. 7b, e, h), with no evidence of entry in the nuclear compartment (Fig. 7a, d, g). To confirm that fluorescently-labelled $\mathrm{aSiO}_{2} \mathrm{NPs}$ did not induce 

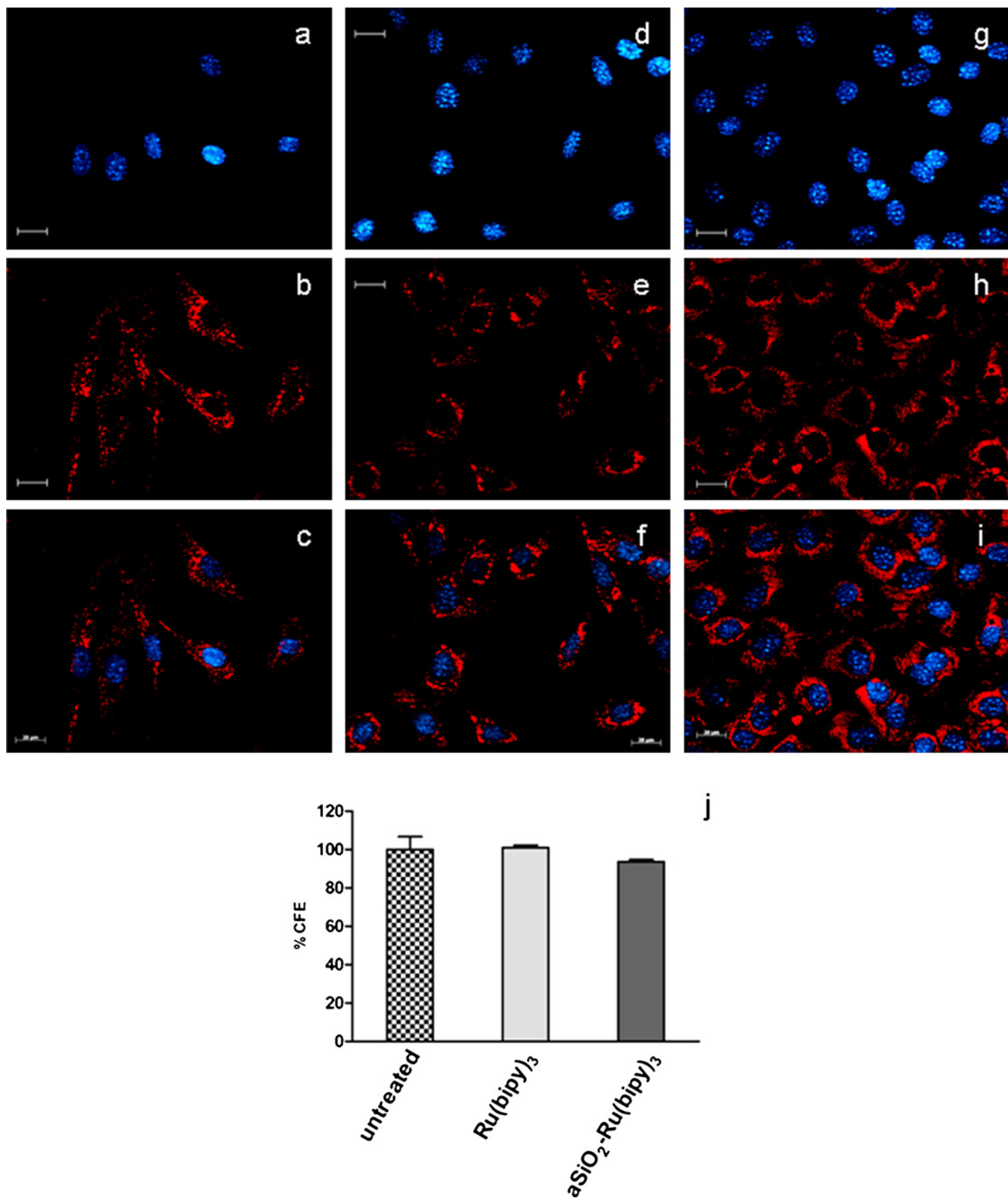

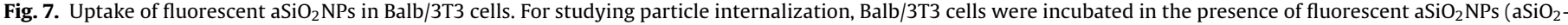

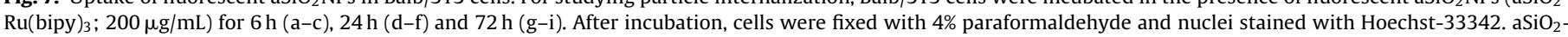

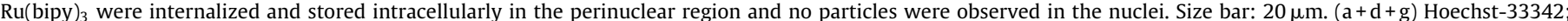

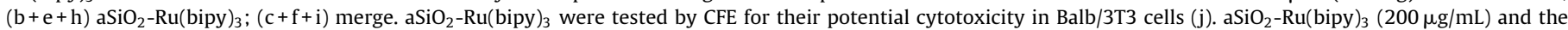
$\mathrm{Ru}(\text { bipy })_{3}$ dye did not induce any toxic effect in Balb/3T3 cells after $72 \mathrm{~h}$ exposure.

cytotoxicity in Balb/3T3 mouse fibroblasts, we performed CFE and, as shown in Fig. $7 \mathrm{j}$, after $72 \mathrm{~h}$ exposure neither $\mathrm{aSiO}_{2}-\mathrm{Ru}(\text { bipy })_{3}$ nor the dye used to label particles impaired the formation of Balb/3T3 colonies.

Taken together, our data indicate that although fluorescent $\mathrm{aSiO}_{2} \mathrm{NPs}$ were internalized in Balb/3T3 mouse fibroblasts and stored in the cytosol, $\mathrm{aSiO}_{2}-\mathrm{Ru}$ (bipy) ${ }_{3}$ do not induce any cytotoxic effect in Balb/3T3 cells. Studies to quantify the uptake of $\mathrm{aSiO}_{2}-\mathrm{Ru}$ (bipy) ${ }_{3}$ as a function of the exposure time are currently ongoing.

\section{Discussion}

Due to the widespread use of $\mathrm{aSiO}_{2} \mathrm{NPs}$ in industrial and biomedical applications, studying the possible toxicological effects of these nanomaterials is of great importance. The aim of this study was to investigate the potential cytotoxicity, morphological transformation and genotoxicity induced by $\mathrm{aSiO}_{2} \mathrm{NPs}$ in $\mathrm{Balb} / 3 \mathrm{~T} 3$ mouse fibroblasts.

The greater part of the published results on the cytotoxic potential of $\mathrm{aSiO}_{2} \mathrm{NPs}$ have been obtained using colorimetric assays such 
as MTT, which is a test that measures the metabolic and mitochondrial activity of the cells and is generally accepted as a cytotoxicity test. MTT has been shown to generate reliable data for cytotoxicity studies with chemical compounds; nevertheless, it has been found to be less reliable in testing the potential cytotoxicity of NPs [43-47]. The impaired cellular viability we have detected by MTT assay in Balb/3T3 cells exposed to NRT-820 might not be due to a loss of the metabolic activity, but rather to the formazan dye interfering with NPs $[43,46]$. To avoid this problem, in this work we decided to use the CFE. This assay has already been used and considered promising to assess the cytotoxicity induced by nanomaterials [46,48-50], since it is a clonogenic assay in which the endpoint is the formation of colonies by those cells surviving after the exposure to the test compound. At the end of the exposure, solutions containing NPs are removed and cells maintained in culture with fresh medium. In this way interactions between the dye used to stain colonies and free test particles are eliminated, thus avoiding any misinterpretation of the experimental outcome [44,46,51].

Although $\mathrm{aSiO}_{2} \mathrm{NPs}$ are generally considered as non-toxic nanomaterials, a number of previous in vitro studies have reported time-, concentration- or particles' size-dependent cytotoxicity induced by $\mathrm{aSiO}_{2} \mathrm{NPs}$. Time-dependent reduction of the cellular viability has been measured by MTT in human hepatic L-02 cells exposed to $21 \mathrm{~nm} \mathrm{SiO}{ }_{2}$ NPs [13]. Moreover, the viability of A549 (human pulmonary epithelial cells) cells has been shown to decrease over the time of exposure ( $24 \mathrm{~h}-48 \mathrm{~h}-72 \mathrm{~h}$ ) in the presence of $15 \mathrm{~nm}$ and $46 \mathrm{~nm} \mathrm{aSiO}_{2}$ NPs [14]. Furthermore, particles' size has been reported as playing a role in the cytotoxicity of $\mathrm{aSiO}_{2} \mathrm{NPs}$ in human umbilical endothelial EAHY96 cells: $\mathrm{aSiO}_{2} \mathrm{NPs}$ with a size diameter of 14-60 nm have affected more rapidly and more severely the survival of EAHY96 cells as compared to $\mathrm{aSiO}_{2} \mathrm{NPs}$ with a diameter above $100 \mathrm{~nm}$ [12]. In HaCaT cells (human keratinocytes) $15 \mathrm{~nm}$ and $30 \mathrm{~nm} \mathrm{aSiO}_{2} \mathrm{NPs}$ induced dose-dependent cytotoxicity and apoptosis. In addition, a more significant cytotoxic effect has been detected, by CCK-8 assay, following the exposure of HaCaT cells to $15 \mathrm{~nm}$ silica NPs [15]. The viability of human kidney HEK293 cells in the presence of $20 \mathrm{~nm}$ and $50 \mathrm{~nm}$ has revealed, by MTT assay, a dose- and time-dependent cytotoxicity and, once again, smaller $\mathrm{aSiO}_{2} \mathrm{NPs}$ were reported inducing higher toxicity compared to larger NPs [20].

Our results have shown that size has not triggered cytotoxicity in Balb/3T3 cells. We have examined $\mathrm{aSiO}_{2} \mathrm{NPs}$ with a size diameter ranging from $16 \mathrm{~nm}$ to $300 \mathrm{~nm}$ and the cellular viability has been impaired only after exposure to $80 \mathrm{~nm}$ particles (NRT-820), which indeed has been shown by electron microscopy as being composed of NPs with size of $40 \mathrm{~nm}$ and $80 \mathrm{~nm}$. This result has been observed not by CFE, but using the colorimetric MTT assay, whose ability in interfering with nanomaterials and, consequently, leading to a possible misinterpretation of the data has already been reported $[46,47,51-53]$. Nevertheless, while MTT is a test able to give immediate information on the metabolic and mitochondrial activity of the cells exposed to a test compound (NPs), the CFE protocol might allow cells to recover and repair any damage induced by the exposure to NPs.

Following exposure to monodispersed $\mathrm{aSiO}_{2} \mathrm{NPs}$ with a larger diameter $(150-200 \mathrm{~nm})$ the cellular viability of mouse microglial cells has not been impaired [17]. Our data have shown that $\mathrm{aSiO}_{2} \mathrm{NPs}$ with size diameter of $200 \mathrm{~nm}(\mathrm{NM}-200)$ and $300 \mathrm{~nm}$ (NM-203) could not induce cytotoxicity in Balb/3T3 cells. However, the absence of toxicity might be due to the fact that these NPs formed huge aggregates and cells were not able to internalize them.

It has been reported that cytotoxicity not only depends on the physicochemical properties of particles, but also varies with the cellular type investigated [22]. Therefore, even if our results are in contrast to other studies performed using different cell lines and different silica NPs, we are confident of the reliability and reproducibility of the CFE assay for testing NPs [49,54].

Little is known about the morphological transformation induced by $\mathrm{aSiO}_{2} \mathrm{NPs}$. Amorphous $\mathrm{SiO}_{2} \mathrm{NPs}$ were reported as inducing morphological transformation in SHE cells [24]. Three different biogenic diatomaceous earths have induced a dose-dependent transformation of SHE cells and, interestingly, pyrogenic amorphous silica has not shown any carcinogenic potential [24].

Elias et al. [24] have postulated that the presence of metal impurities might be responsible for morphological transformation detected in SHE cells. In fact, iron and aluminium were found on the surface of the biogenic diatomaceous earth NPs, which have induced morphological transformation whereas pyrogenic $\mathrm{aSiO}_{2} \mathrm{NPs}$, free of these elements, have not shown carcinogenic potential in SHE cells [24].

In addition, after being heated diatomaceous earth silica nanoparticles were shown to induce morphological transformation in SHE cells [25]. Compared to non-heated biogenic diatomaceous silica, which did not induce any effect, a dose-dependent increase has been observed in transformed SHE cells exposed to diatomaceous silica, which had been heated to up to $900^{\circ} \mathrm{C}$ and $1200^{\circ} \mathrm{C}$ [25]. As possible explanation, Elias et al. [25] have reported that heating of diatomaceous earth silica induces crystallization of the samples and the formation of free radicals and particle-derived ROS, which have already been demonstrated as the key factor in quartz-induced cell transformation [55-57] and biogenic earth silica-induced cell transformation [21].

Our $\mathrm{aSiO}_{2} \mathrm{NPs}$, in contrast, have not been able to induce morphological transformation in Balb/3T3 cells, irrespective of size and synthesis method. Neither small $(16-80 \mathrm{~nm})$ water dispersed $\mathrm{aSiO}_{2} \mathrm{NPs}$ nor larger $(200 \mathrm{~nm})$ silica particles nor pyrogenic $\mathrm{aSiO}_{2} \mathrm{NPs}$ (NM-203; $300 \mathrm{~nm}$ size diameter) have shown any carcinogenic potential in vitro in Balb/3T3 mouse fibroblasts, suggesting that other factors than the presence of metal residues on the particles' surface might be responsible for triggering morphological transformation in Balb/3T3 cells in vitro.

Only a few studies have investigated the potential genotoxicity of $\mathrm{aSiO}_{2}$ NPs. Using the Comet assay Barnes et al. [29] have demonstrated that alumina-coated silica NPs with size diameter ranging from $20 \mathrm{~nm}$ to $250 \mathrm{~nm}$ are not genotoxic in 3T3-L1 mouse fibroblasts. Furthermore, $50 \mathrm{~nm}$ luminescent silica particles have not exerted any genotoxicity in A549 cells [32]. In fact, Comet assay, Western blot analysis of the DNA and DNA agarose gel have not shown any significant DNA damage or any increased DNA repair activity in A549 following exposure to $\mathrm{SiO}_{2} \mathrm{NPs}$, leading the authors to suggest that $\mathrm{SiO}_{2} \mathrm{NPs}$ were not able to induce genotoxicity because NPs have not penetrated in the nuclei [30].

Interestingly, a cell type-dependent, and not concentration- or size-dependent, genotoxicity (reduction of the DNA content) was observed by Cha and Myung [27]: among the different cell lines examined, brain (A-172) and liver (Huh-7) cells have responded more quickly than stomach (MKN-1) and lung (A549) cells to $\mathrm{aSiO}_{2} \mathrm{NPs}$.

In addition, sub-toxic doses of $16 \mathrm{~nm}, 60 \mathrm{~nm}$ and $104 \mathrm{~nm}$ amorphous silica NPs did not induce any significant formation of micronuclei in A549 [26]. The smallest silica NPs (16 nm) were reported as inducing slightly higher micronuclei formation than the $60 \mathrm{~nm}$ and $104 \mathrm{~nm} \mathrm{aSiO}_{2} \mathrm{NPs}$, although the micronuclei formation was not significant [26]. Accordingly, we have demonstrated that, independently of their size, following exposure to $\mathrm{aSiO}_{2} \mathrm{NPs}$ no micronuclei formation has been detected in Balb/3T3 cells, suggesting that under the experimental conditions we have applied $\mathrm{aSiO}_{2} \mathrm{NPs}$ are not genotoxic.

To verify whether or not $\mathrm{aSiO}_{2} \mathrm{NPs}$ induce cytotoxicity, morphological transformation and genotoxicity in Balb/3T3 mouse fibroblasts in vitro, the uptake of $\mathrm{aSiO}_{2} \mathrm{NPs}$ has been investigated. 
After characterization, $85 \mathrm{~nm}$ fluorescently-labelled silica nanoparticles $\left(\mathrm{aSiO}_{2}-\mathrm{Ru} \text { (bipy) }\right)_{3} \mathrm{NPs}$ ) were selected for the study. From Jin et al. [30] it is already known that $50 \mathrm{~nm} \mathrm{Ru(bipy)})_{3}$-labelled silica nanoparticles do not induce cytotoxic effects in A549 human pneumocytes. Similarly, we have observed that $80 \mathrm{~nm} \mathrm{Ru(bipy)_{3 } -}$ labelled $\mathrm{aSiO}_{2} \mathrm{NPs}$ have not exerted cytotoxicity in Balb/3T3 mouse fibroblasts in vitro.

In contrast, Chen and von Mikecz [28] have demonstrated that 40-70 nm fluorescent silica NPs exerted toxic effects inhibiting the replication and the cellular proliferation of HEp-2 human cells. Furthermore, $70 \mathrm{~nm}$ fluorescent $\mathrm{SiO}_{2} \mathrm{NPs}$ were shown to damage the integrity of the cell membrane and have induced cytotoxicity in HeLa cells incubated in the absence of serum proteins. In this case the authors have suggested that serum proteins covered the particles' surface, preventing the direct interaction, and therefore the damage, to the cell membrane [31].

The intracellular localization of silica NPs has also been investigated and the results are not conclusive. On one side, Jin et al. [30] have reported that, after $6 \mathrm{~h}$ incubation, $50 \mathrm{~nm} \mathrm{Ru}$ (bipy) $)_{3}$-labelled silica nanoparticles become localized in the cytoplasmic compartment of A549 human pneumocytes but have not crossed the nuclear membrane. In the same way we have observed that $85 \mathrm{~nm} \mathrm{aSiO}{ }_{2}$ $\mathrm{Ru}$ (bipy) ${ }_{3}$ NPs have accumulated exclusively in the cytoplasm of Balb/3T3 cells and have not entered the nuclei, and that the internalization of $\mathrm{aSiO}_{2}-\mathrm{Ru}$ (bipy) ${ }_{3} \mathrm{NPs}$ in Balb/3T3 mouse fibroblasts has occurred already within $6 \mathrm{~h}$ exposure.

Similarly, $13 \mathrm{~nm}$ fluorescent silica-capped CdSe-CdS NPs were observed in the perinuclear region of A549 cells [32], and $70 \mathrm{~nm}$ fluorescent $\mathrm{SiO}_{2}$ particles were observed in the lysosomal compartment of HeLa cells, whilst sub-micron ( $200 \mathrm{~nm}$ and $500 \mathrm{~nm}$ size diameter) fluorescent $\mathrm{SiO}_{2}$ particles were found in the cytoplasm and in the endosomes of HeLa cells [31].

In contrast, Chen and von Mikecz [28] have shown that 40-70 nm fluorescent silica NPs entered the nuclei of HEp-2 cells, while fine $(0.2 \mu \mathrm{m}$ size $)$ and coarse ( $5 \mu \mathrm{m}$ size) $\mathrm{SiO}_{2}$ NPs accumulated exclusively in the cytoplasm. As possible explanation the authors have suggested that the size of nanoparticles contributes to the effects exerted by $\mathrm{SiO}_{2} \mathrm{NPs}$ : $\mathrm{small} \mathrm{SiO}_{2} \mathrm{NPs}$ entering into the nuclei have inhibited gene expression in HEp-2 cells, whereas larger particles $(>200 \mathrm{~nm})$ have not crossed the nuclear membrane and have not exerted any effect.

\section{Conclusions}

In conclusion, we have shown that when dispersed in cell culture medium $\mathrm{aSiO}_{2} \mathrm{NPs}$ were colloidally stable, with the exception of NM-200 and NM-203. NM-200 and NM-203 solutions were prepared from powder stocks, for which the dispersion protocol was unable to break the NP aggregates formed. As a consequence, the redispersed samples were composed of particles with much larger mean diameter than that expected from the data declared by the suppliers. Aggregation/agglomeration of NM-200 and NM203 , however, does not seem to play a role as these particles were observed inducing a non-significant toxic effect in Balb/3T3 mouse fibroblasts as the monodispersed NRT-808, NRT-817 and NRT-820.

Using the CFE assay we have shown that $\mathrm{aSiO}_{2} \mathrm{NPs}$ do not induce cytotoxicity in Balb/3T3 mouse fibroblasts. Moreover, the CTA and MN test demonstrated that the investigated $\mathrm{aSiO}_{2} \mathrm{NPs}$ were not able to induce morphological transformation or genotoxicity in Balb/3T3 cells, respectively.

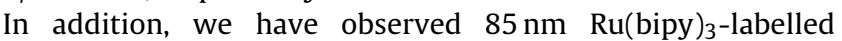
$\mathrm{aSiO}_{2} \mathrm{NPs}$ internalized and stored in the perinuclear region of $\mathrm{Balb} / 3 \mathrm{~T} 3$ cells, supporting the evidence that although $\mathrm{aSiO}_{2} \mathrm{NPs}$ were taken up by cells, they have not triggered any toxic effect.
While these results are encouraging regarding the low toxicity of $\mathrm{aSiO}_{2} \mathrm{NPs}$, their very widespread use in industrial applications, such as cosmetics, and their potential use in biomedicine means there is still great relevance in performing additional studies to investigate any potential DNA strand breaks induced by $\mathrm{aSiO}_{2} \mathrm{NPs}$, as well as the ability of $\mathrm{aSiO}_{2} \mathrm{NPs}$ to induce the secretion of proinflammatory cytokines. In addition, due to the potential use of $\mathrm{aSiO}_{2} \mathrm{NPs}$ in drug delivery and cancer therapy, further studies to better clarify the endocytotic pathway of $\mathrm{aSiO}_{2} \mathrm{NPs}$ and their intracellular fate (accumulation and/or recycling) are needed.

\section{Conflict of interest}

None.

\section{Acknowledgments}

The authors would like to thank Dr. César Pascual García for SEM imaging and analysis. This work was conducted in part with support from activities in the European Commission funded collaborative project NanoReTox (FP7-NMP-2007-SMALL-1).

\section{References}

[1] J.R.C.J.o.t.E. Commission, http://cordis.europa.eu/nanotechnology/actionplan. htm.

[2] OECD, Working Party on Manufactured Nanomaterials, Series on the Safety of Manufactured Nanomaterials No. 27, ENV/JM/MONO(2010)46, 2010.

[3] OECD, Reference Nanomaterials program, http://ihcp.jrc.ec.europa.eu/ our_activities/nanotechnology/reference-nanomaterials.

[4] J. Lu, M. Liong, J.I. Zink, F. Tamanoi, Mesoporous silica nanoparticles as a delivery system for hydrophobic anticancer drugs, Small 3 (2007) 1341-1346.

[5] T. Xia, M. Kovochich, M. Liong, H. Meng, S. Kabehie, S. George, J.I. Zink, A.E. Nel, Polyethyleneimine coating enhances the cellular uptake of mesoporous silica nanoparticles and allows safe delivery of siRNA and DNA constructs, ACS Nano 3 (2009) 3273-3286

[6] S. Dekkers, P. Krystek, R.J. Peters, D.X. Lankveld, B.G. Bokkers, P.H. van HoevenArentzen, H. Bouwmeester, A.G. Oomen, Presence and risks of nanosilica in food products, Nanotoxicology 5 (2010) 393-405.

[7] D.M. Huang, Y. Hung, B.S. Ko, S.C. Hsu, W.H. Chen, C.L. Chien, C.P. Tsai, C.T. Kuo, J.C. Kang, C.S. Yang, C.Y. Mou, Y.C. Chen, Highly efficient cellular labeling of mesoporous nanoparticles in human mesenchymal stem cells: implication for stem cell tracking, FASEB J. 19 (2005) 2014-2016.

[8] H. Shi, X. He, Y. Yuan, K. Wang, D. Liu, Nanoparticle-based biocompatible and long-life marker for lysosome labeling and tracking, Anal. Chem. 82 (2010) 2213-2220.

[9] L.R. Hirsch, R.J. Stafford, J.A. Bankson, S.R. Sershen, B. Rivera, R.E. Price, J.D. Hazle, N.J. Halas, J.L. West, Nanoshell-mediated near-infrared thermal therapy of tumors under magnetic resonance guidance, Proc. Natl. Acad. Sci. U.S.A. 100 (2003) 13549-13554

[10] S.M. Moghimi, A.C. Hunter, J.C. Murray, Nanomedicine: current status and future prospects, FASEB J. 19 (2005) 311-330.

[11] S.J. Choi, J.M. Oh, J.H. Choy, Toxicological effects of inorganic nanoparticles on human lung cancer A549 cells, J. Inorg. Biochem. 103 (2009) 463-471.

[12] D. Napierska, L.C. Thomassen, V. Rabolli, D. Lison, L. Gonzalez, M. KirschVolders, J.A. Martens, P.H. Hoet, Size-dependent cytotoxicity of monodisperse silica nanoparticles in human endothelial cells, Small 5 (2009) 846-853.

[13] Y. Ye, J. Liu, J. Xu, L. Sun, M. Chen, M. Lan, Nano-SiO 2 induces apoptosis via activation of $\mathrm{p} 53$ and Bax mediated by oxidative stress in human hepatic cell line, Toxicol. In Vitro 24 (2010) 751-758.

[14] W. Lin, Y.W. Huang, X.D. Zhou, Y. Ma, In vitro toxicity of silica nanoparticles in human lung cancer cells, Toxicol. Appl. Pharmacol. 217 (2006) 252-259.

[15] X. Yang, J. Liu, H. He, L. Zhou, C. Gong, X. Wang, L. Yang, J. Yuan, H. Huang, L. He, B. Zhang, Z. Zhuang, $\mathrm{SiO}_{2}$ nanoparticles induce cytotoxicity and protein expression alteration in HaCaT cells, Part. Fibre Toxicol. 7 (2010) 1.

[16] H.J. Eom, J. Choi, Oxidative stress of silica nanoparticles in human bronchial epithelial cell, Beas-2B, Toxicol. In Vitro 23 (2009) 1326-1332.

[17] J. Choi, Q. Zheng, H.E. Katz, T.R. Guilarte, Silica-based nanoparticle uptake and cellular response by primary microglia, Environ. Health Perspect. 118 (2010) 589-595.

[18] D. Dutta, S.K. Sundaram, J.G. Teeguarden, B.J. Riley, L.S. Fifield, J.M. Jacobs, S.R. Addleman, G.A. Kaysen, B.M. Moudgil, T.J. Weber, Adsorbed proteins influence the biological activity and molecular targeting of nanomaterials, Toxicol. Sci. 100 (2007) 303-315.

[19] E.J. Park, K. Park, Oxidative stress and pro-inflammatory responses induced by silica nanoparticles in vivo and in vitro, Toxicol. Lett. 184 (2009) 18-25.

[20] F. Wang, F. Gao, M. Lan, H. Yuan, Y. Huang, J. Liu, Oxidative stress contributes to silica nanoparticle-induced cytotoxicity in human embryonic kidney cells, Toxicol. In Vitro 23 (2009) 808-815. 
[21] B. Fubini, I. Fenoglio, Z. Elias, O. Poirot, Variability of biological responses to silicas: effect of origin, crystallinity, and state of surface on generation of reactive oxygen species and morphological transformation of mammalian cells, J. Environ. Pathol. Toxicol. Oncol. 20 (Suppl. 1) (2001) 95-108.

[22] V. Rabolli, L.C. Thomassen, C. Princen, D. Napierska, L. Gonzalez, M. KirschVolders, P.H. Hoet, F. Huaux, C.E. Kirschhock, J.A. Martens, D. Lison, Influence of size, surface area and microporosity on the in vitro cytotoxic activity of amorphous silica nanoparticles in different cell types, Nanotoxicology 4 (2010) 307-318

[23] T. Morishige, Y. Yoshioka, H. Inakura, A. Tanabe, X. Yao, S. Narimatsu, Y. Monobe, T. Imazawa, S. Tsunoda, Y. Tsutsumi, Y. Mukai, N. Okada, S. Nakagawa, The effect of surface modification of amorphous silica particles on NLRP3 inflammasome mediated IL-1beta production, ROS production and endosomal rupture, Biomaterials 31 (2010) 6833-6842.

[24] Z. Elias, O. Poirot, M.C. Daniere, F. Terzetti, A.M. Marande, S. Dzwigaj, H. Pezerat, I. Fenoglio, B. Fubini, Cytotoxic and transforming effects of silica particles with different surface properties in Syrian hamster embryo (SHE) cells, Toxicol. In Vitro 14 (2000) 409-422.

[25] Z. Elias, O. Poirot, I. Fenoglio, M. Ghiazza, M.C. Daniere, F. Terzetti, C. Darne, C. Coulais, I. Matekovits, B. Fubini, Surface reactivity, cytotoxic, and morphological transforming effects of diatomaceous Earth products in Syrian hamster embryo cells, Toxicol. Sci. 91 (2006) 510-520.

[26] L. Gonzalez, L.C. Thomassen, G. Plas, V. Rabolli, D. Napierska, I. Decordier, M. Roelants, P.H. Hoet, C.E. Kirschhock, J.A. Martens, D. Lison, M. Kirsch-Volders, Exploring the aneugenic and clastogenic potential in the nanosize range: A549 human lung carcinoma cells and amorphous monodisperse silica nanoparticles as models, Nanotoxicology 4 (2010) 382-395.

[27] K.E. Cha, H. Myung, Cytotoxic effects of nanoparticles assessed in vitro and in vivo, J. Microbiol. Biotechnol. 17 (2007) 1573-1578.

[28] M. Chen, A. von Mikecz, Formation of nucleoplasmic protein aggregates impairs nuclear function in response to $\mathrm{SiO}_{2}$ nanoparticles, Exp. Cell Res. 305 (2005) 51-62.

[29] C.A. Barnes, A. Elsaesser, J. Arkusz, A. Smok, J. Palus, A. Lesniak, A. Salvati, J.P. Hanrahan, W.H. Jong, E. Dziubaltowska, M. Stepnik, K. Rydzynski, G. McKerr, I. Lynch, K.A. Dawson, C.V. Howard, Reproducible comet assay of amorphous silica nanoparticles detects no genotoxicity, Nano Lett. 8 (2008) 3069-3074.

[30] Y. Jin, S. Kannan, M. Wu, J.X. Zhao, Toxicity of luminescent silica nanoparticles to living cells, Chem. Res. Toxicol. 20 (2007) 1126-1133.

[31] M. Al-Rawi, S. Diabate, C. Weiss, Uptake and intracellular localization of submicron and nano-sized $\mathrm{SiO}_{2}$ particles in HeLa cells, Arch. Toxicol. 85 (2011) 813-826

[32] I. Stayton, J. Winiarz, K. Shannon, Y. Ma, Study of uptake and loss of silica nanoparticles in living human lung epithelial cells at single cell level, Anal. Bioanal. Chem. 394 (2009) 1595-1608.

[33] T. Kakunaga, A quantitative system for assay of malignant transformation by chemical carcinogens using a clone derived from BALB-3T3, Int. J. Cancer 12 (1973) 463-473.

[34] T. Kakunaga, J.D. Crow, Cell variants showing differential susceptibility to ultraviolet light-induced transformation, Science 209 (1980) 505-507.

[35] P. Vanparys, R. Corvi, M. Aardema, L. Gribaldo, M. Hayashi, S. Hoffmann, L. Schechtman, ECVAM prevalidation of three cell transformation assays, ALTEX 28 (2010) 56-59.

[36] K.D. Hartlen, A.P. Athanasopoulos, V. Kitaev, Facile preparation of highly monodisperse small silica spheres ( 15 to $>200 \mathrm{~nm}$ ) suitable for colloidal templating and formation of ordered arrays, Langmuir 24 (2008) 1714-1720.

[37] L. Ceriotti, J. Ponti, P. Colpo, E. Sabbioni, F. Rossi, Assessment of cytotoxicity by impedance spectroscopy, Biosens. Bioelectron. 22 (2007) 3057-3063.

[38] W.g. IARC/NCI/EPA, Cellular and molecular mechanisms of cell transformation and standardization of transformation assays of established cell lines for the prediction of carcinogenic chemicals: overview and recommended protocols, Cancer Res. 45 (1985) 2395-2399.
[39] J. Ponti, B. Munaro, M. Fischbach, S. Hoffmann, E. Sabbioni, An optimised data analysis for the Balb/c 3T3 cell transformation assay and its application to metal compounds, Int. J. Immunopathol. Pharmacol. 20 (2007) 673-684.

[40] L. Calzolai, D. Gilliland, C.P. Garcia, F. Rossi, Separation and characterization of gold nanoparticle mixtures by flow-field-flow fractionation, J. Chromatogr. A 1218 (2011) 4234-4239.

[41] B. Berne, R. Pecora, Dynamic Light Scattering with Applications to Chemistry Biology, and Physics, Dover, Mineola, 2000.

[42] V. Filipe, A. Hawe, W. Jiskoot, Critical evaluation of Nanoparticle Tracking Analysis (NTA) by Nanosight for the measurement of nanoparticles and protein aggregates, Pharm. Res. 27 (2010) 796-810.

[43] J.M. Worle-Knirsch, K. Pulskamp, H.F. Krug, Oops they did it again! Carbon nanotubes hoax scientists in viability assays, Nano Lett. 6 (2006) 1261-1268.

[44] N.A. Monteiro-Riviere, A.O. Inman, Challenges for assessing carbon nanomaterial toxicity to the skin, Carbon 44 (2006) 1070-1078.

[45] A. Casey, E. Herzog, M. Davoren, F.M. Lyng, H.J. Byrne, G. Chambers, Spectroscopic analysis confirms the interactions between single walled carbon nanotubes and various dyes commonly used to assess cytotoxicity, Carbon 45 (2007) 1425-1432.

[46] N.A. Monteiro-Riviere, S.J. Oldenburg, A.O. Inman, Interactions of aluminum nanoparticles with human epidermal keratinocytes, J. Appl. Toxicol. 30 (2010) 276-285.

[47] M. Horie, K. Nishio, K. Fujita, S. Endoh, A. Miyauchi, Y. Saito, H. Iwahashi, K. Yamamoto, H. Murayama, H. Nakano, N. Nanashima, E. Niki, Y. Yoshida, Protein adsorption of ultrafine metal oxide and its influence on cytotoxicity toward cultured cells, Chem. Res. Toxicol. 22 (2009) 543-553.

[48] L. Ceriotti, A. Kob, S. Drechsler, J. Ponti, E. Thedinga, P. Colpo, R. Ehret, F. Rossi, Online monitoring of BALB/3T3 metabolism and adhesion with multiparametric chip-based system, Anal. Biochem. 371 (2007) 92-104.

[49] J. Ponti, R. Colognato, H. Rauscher, S. Gioria, F. Broggi, F. Franchini, C. Pascual, G. Giudetti, F. Rossi, Colony forming efficiency and microscopy analysis of multiwall carbon nanotubes cell interaction, Toxicol. Lett. 197 (2010) 29-37.

[50] J. Ponti, E. Sabbioni, B. Munaro, F. Broggi, P. Marmorato, F. Franchini, R. Colognato, F. Rossi, Genotoxicity and morphological transformation induced by cobalt nanoparticles and cobalt chloride: an in vitro study in Balb/3T3 mouse fibroblasts, Mutagenesis 24 (2009) 439-445.

[51] N.A. Monteiro-Riviere, A.O. Inman, L.W. Zhang, Limitations and relative utility of screening assays to assess engineered nanoparticle toxicity in a human cel line, Toxicol. Appl. Pharmacol. 234 (2009) 222-235.

[52] M. Davoren, E. Herzog, A. Casey, B. Cottineau, G. Chambers, H.J. Byrne, F.M. Lyng, In vitro toxicity evaluation of single walled carbon nanotubes on human A549 lung cells, Toxicol. In Vitro 21 (2007) 438-448.

[53] M. Horie, K. Nishio, K. Fujita, H. Kato, A. Nakamura, S. Kinugasa, S. Endoh, A Miyauchi, K. Yamamoto, H. Murayama, E. Niki, H. Iwahashi, Y. Yoshida, J. Nakanishi, Ultrafine $\mathrm{NiO}$ particles induce cytotoxicity in vitro by cellular uptake and subsequent Ni(II) release, Chem. Res. Toxicol. 22 (2009) 1415-1426.

[54] J. Ponti, L. Ceriotti, B. Munaro, M. Farina, A. Munari, M. Whelan, P. Colpo, E. Sabbioni, F. Rossi, Comparison of impedance-based sensors for cell adhesion monitoring and in vitro methods for detecting cytotoxicity induced by chemicals, Altern. Lab. Anim. 34 (2006) 515-525

[55] L.N. Daniel, Y. Mao, A.O. Williams, U. Saffiotti, Direct interaction between crystalline silica and DNA - a proposed model for silica carcinogenesis, Scand. J. Work Environ. Health 21 (Suppl 2) (1995) 22-26.

[56] L.N. Daniel, Y. Mao, T.C. Wang, C.J. Markey, S.P. Markey, X. Shi, U. Saffiotti, DNA strand breakage, thymine glycol production, and hydroxyl radical generation induced by different samples of crystalline silica in vitro, Environ. Res. 71 (1995) 60-73.

[57] U. Saffiotti, L.N. Daniel, Y. Mao, X. Shi, A.O. Williams, M.E. Kaighn, Mechanisms of carcinogenesis by crystalline silica in relation to oxygen radicals, Environ. Health Perspect. 102 (Suppl 10) (1994) 159-163. 